\title{
A Review on Employability Skills
}

\author{
${ }^{1}$ K.Venkateswarlu, ${ }^{2}$ P.Vara Prasad \\ ${ }^{I}$ Assistant Professor, Department of Management Studies, Gayatri Vidya Parishad College for Degree and PG \\ Courses, Andhra University Visakhapatnam-530045 India \\ ${ }^{2}$ Audit Executive, HSBC HDPI Visakhapatnam India
}

\begin{abstract}
A Skill is defined as an ability and capacity acquired through deliberate, systematic, and sustained effort to smoothly and adaptively carryout complex activities or job functions involving ideas (cognitive skills), things (technical skills), and/or people (interpersonal skills). These days the employers are looking for the candidates who possess more knowledge about various functions and different fields. From organizational perspective, certain skills are very essential to be successful in the job front. Those skills are considered to be the Employability Skills.Employability skills are defined as "the skills required not only to gaining employment, but also to progress within an enterprise so as to achieve one's potential and contribute successfully to the firm's strategic directions". Employability skills can also be referred to as generic skills, capabilities, enabling skills or key competencies. These skills were seen to have a relevance to entry-level, as well as established employees. These skills not only require mere communication skills but also a wide range of additional skills such as leadership, influential skills, initiation skills, which would help them and also the organization to succeed in the competitive market. The paper majorly focuses on those employability skills that have to be possessed by the individuals, their importance in organizational perspective and techniques to be followed to develop the required employability skills.
\end{abstract}

Key Words: Communication Skills, Employability skills, Generic skills, Leadership skills, Skills.

\section{Introduction}

A Skill is defined as an ability and capacity acquired through deliberate, systematic, and sustained effort to smoothly and adaptively carryout complex activities or job functions involving ideas (cognitive skills), things (technical skills), and/or people (interpersonal skills). These skills may be any of any type such as cognitive skills which focuses on thinking patterns in the form of coming up with ideas, technical skills which includes the skill of dealing with things or objects effectively or interpersonal skills. All these are very much essential if any person has to survive in this competitive era of technology and knowledge.

These days the employers are looking for the candidates who possess more knowledge about various functions and different fields. From organizational perspective, certain skills are very essential to be successful in the job front. Those skills are considered to be the Employability Skills .Employability skills are defined as "the skills required not only to gaining employment, but also to progress within an enterprise so as to achieve one's potential and contribute successfully to the firm's strategic directions". Employability skills can also be referred to as generic skills, capabilities, enabling skills or key competencies. These skills were seen to have a relevance to entry-level, as well as established employees. These skills not only require mere communication skills but also a wide range of additional skills such as leadership, influential skills, initiation skills, which would help them and also the organization to succeed in the competitive market.

\section{Objectives of the Paper}

The major objectives of the paper are

- To identify various employability skills that are expected by the employers these days.

- To explain the importance of these skills in job front

- To offer some techniques on how to develop these employability skills

Methodology of the Study

The data is mainly collected through secondary sources such as journals, referred text books, internet.

\section{Concept of employability skills}

Employability skills are defined as "The skills required not only to gain employment, but also to progress within an enterprise so as to achieve one's potential and contribute successfully to the firm's strategic directions". Employability skills can also be referred to as generic skills, capabilities, enabling skills or key competencies. Possession of these qualities can definitely be an added advantage to any person who aspires for a job and for a prosperous career. 
The study classifies employability skills into three major segments which are further divided into sub segments namely: Communication skills segment that includes the basic communication skills (Listening, Speaking, Reading, and Writing), Managerial skills which include (Planning and Organizing, Initiation, Adaptability, Leadership, Motivating \& Decision making) and Analytical skills that include Commercial awareness, Market analysis \& research and Investigating skills.

Development of these skills enables a starter in an organization to get successfully acquainted and inducted to the organizational culture and Enhancement of these skills enables an already existing employee to excel in various forefronts thus avoiding unexpected and unwanted situations during recession such as retrenchment, layoff etc. Enhancement of employability skills is equally important to the senior management people as it allows to go beyond the point where in, their career seems to be stagnant, technically termed as Career Plateuing.

\subsection{Communication Skills}

Any person must and should posses these skills in order to express his or her feelings, ideas, and thoughts. The degree of expression of thoughts differs from one to another depending upon the range of excellence in managing the factors that define communication skills namely Listening, Speaking, Reading, and Writing.

2.1(a) Listening: This skill contributes to $53 \%$ of communication in our daily life. Listening differs from Hearing as the latter is concerned with just picking up the sound from the source and the former includes both hearing and thinking about the same at the same time. Listening makes a sense to what we hear. Listening means paying attention, interpreting what is heard, remembering and making it as stimuli. Mere hearing does not create any change in the enhancement of skills of the individual.

Listening skills may be developed by: Attending to lectures/speeches, making smooth transitions and restating what the speaker has said in the listener's own words, etc.

2.1(b) Speaking: Speaking skills contribute to $16 \%$ of communication in our daily life. Even though people posses sound knowledge and information, they fail in expressing due to lack of satisfactory level of speaking skills. Speaking with good sense of situational analysis and information would yield good results.

Speaking skills may be developed through: Public speaking or debating, Presenting in seminars and Counseling the individuals in order to avoid fear that hinders speaking skills.

2.1(c) Reading: In general, reading contributes to $17 \%$ of communication. Reading has two major advantages namely enhancement of knowledge in the subject being read and improvement of verbal ability. Reading can be classified into two categories on the basis of content being extracted .They are: Extensive Reading in which a general understanding of a subject is obtained and Intensive Reading in which specific and particular information of a subject is extracted.

Reading skills may be developed through

1. Picking up chunks of words instead of single words or two words

2. Don't go for the dictionary as its use would be fruitful only when reading skill is developed.

2.1(d) writing: Writing contributes to $14 \%$ of our communication. Practicing writing skills results in the development of an individual's thinking ability. Writing skills may be developed through: Writing up a project or dissertation or essays, Writing for the student newspaper and writing Letters to raise sponsorship for an event.

\subsection{Managerial Skills}

Managerial skills refer to those skills that help an individual in managing a team and achieving the desired results in a particular course of action. Some of the managerial skills include:

2.2(a) Planning and Organizing: Planning includes deciding how-about of a course of action and Organizing includes arranging the resources in an organized way. Planning helps in managing the workload of several courses simultaneously; meeting the deadlines; designing and carrying out assigning tasks. Organizing helps in effective utilization of resources without any wastage and complexity. It's a fact that exceptional planning without proper organizing and implementation yields poor results. To the contrary, an average plan with proper organizing and implementation would yield better results.

2.2(b) Decision Making: Decision making is one of the important aspects in which one best alternative among many has to be chosen cautiously. Planning and decision making are interconnected. Sound planning leads to sound decision making. Choosing the right decision at right time, at right place is a tough task. The person has to take several factors into consideration as far as decision making is concerned. Decision making skills can be developed by:

- Thorough interpretation of information in several ways

- Understanding the past situations in different conditions 
2.2(c) Initiation Skills: Initiation is taking one step ahead post the phase of planning. The people who have initiation skills are given importance in the competitive situations. It is observed only a few people who have good initiation skills are given importance.

2.2(d) Leadership Skills: These skills come into picture in those situations where the tasks seem to be gigantic and cannot be carried by a single person. Under such circumstances a group of individuals have to carry out the task and the person among all the members in the group who possesses leadership skills can successfully manage the task by leading the group. Leadership simply means directing the followers towards a goal. Leadership skills can be developed by: Taking initiation, acquiring sense of responsibility, etc.

2.2(e) Adaptability Skills: Development of these skills is crucial both for the organization as well as the individuals since they operate in a highly sensitive business environment. This enables them to tune themselves to the changes, thus making them to withstand various technical or technological changes. These skills can be developed by having a clear vision of the future and by anticipating the future business trends and designing programs as per the trends. The programs can be either focused on upgrading the technical aspects of the employees or preparing them psychologically to the changes anticipated.

\subsection{Analytical Skills}

Development of Analytical skills is particularly important to those who aspire to be entrepreneurs and also to those who strive to attain senior managerial cadre. These provide a detailed understanding of the existing business scenarios and the requirements demanded by those scenarios. In an organizational context, analytical skills include: Market Analysis \& Research, Commercial Awareness \& Investigating skills.

Market analysis \& research skills can be developed by individuals by obtaining necessary information about those companies that operate in his/her segment of interest. This includes not only the collection but also a detailed interpretation of the gathered data. Investigating skills are similar to the skills mentioned above but, the difference between them lies in the intensity of application of research abilities i.e., in market analysis, one has to get the basic data of entire market segment and in investigation phase, one has to peep into the companies affairs and try to identify the problems faced by the firm and come out with possible solutions.

Commercial Awareness skills can be developed by taking the individuals through a company's performance in financial parameters such as assessment of current value of the firm's share with respect to its previous performance and also to its competitors.

\section{Conclusion}

The individuals who tend to gain employment have to focus on polishing their innate skills and also on putting efforts to acquire additional skills that are demanded by the employers. Academic institutions have to play a significant role in designing effective and efficient programmes that can develop employability skills in the individuals in order to make them cater to the needs of the organization

\section{References}

[1] G.S.R.K.Babu Rao, Business Communication and soft skills, Himalaya Publishing House, Mumbai.

[2] P.Subba Rao, Organizational Behaviour by, Himalaya Publishing House, Mumbai.

[3] Retrieved from the source http://www.kent.ac.uk/careers/sk/skillsdevelop.html

[4] Retrieved from the source http://www.kent.ac.uk/careers/sk/skillsmenu.htm

[5] Retrieved from : http://labour.nic.in/policy/NationalSkillDevelopmentPolicyMar09.pdf 